\title{
Perbandingan Ekstraksi Fitur dan Proses Matching pada Autentikasi Sidik Jari Manusia
}

\section{ANGGUNMEKA LUHUR PRASASTI ${ }^{1}$, BUDHI IRAWAN ${ }^{1}$, SETIO EKA FAJRI ${ }^{1}$, ANANDA RENDIKA ${ }^{1}$, SUGONDO HADIYOSO ${ }^{2}$}

\author{
${ }^{1}$ Fakultas Teknik Elektro, Telkom University, Indonesia \\ ${ }^{2}$ Fakultas IImu Terapan, Telkom University, Indonesia \\ Email : anggunmeka@telkomuniversity.ac.id
}

Received 27 Agustus 2019 | Revised 10 September 2019 | Accepted 21 Oktober 2019

\begin{abstract}
ABSTRAK
Sidik jari merupakan biometrik yang sering digunakan dalam teknologi autentikasi. Terdapat banyak metode yang bisa digunakan untuk membuat sistem klasifikasi sidik jari. Maximum Curvature Points (MCP) umumnya digunakan untuk ekstraksi citra pembuluh darah jari yang juga digunakan sebagai autentikasi. Pada penelitian ini akan diuji performansi dari metode MCP jika dibandingkan dengan metode yang umum digunakan pada proses pengenalan sidik jari, yaitu Hit and Miss Transform (HMT). Perbedaan domain, yaitu spasial pada Normalized Cross Correlation (NCC) dan frekuensi pada Phase Correlation (PC) dalam proses matching ternyata juga mempengaruhi performansi sistem. Hasilnya menunjukkan bahwa penggunakaan metode MHTNCC memiliki tingkat akurasi yang lebih baik dalam pengenalan sidik jari yaitu 92\% untuk pengenalan ibu jari dan 98\% untuk pengenalan jari telunjuk, dibandingkan dengan menggunakan metode MCP-PC yang hanya memiliki tingkat akurasi sebesar $88 \%$ untuk pengenalan ibu jari dan 92\% untuk pengenalan jari telunjuk.
\end{abstract}

Kata kunci: sidik jari, MCP, HMT, phase correlation, normalized cross correlation

\begin{abstract}
Fingerprint is one of the biometric systems that are often used in an authentication technology. There are many methods that can be used to develop fingerprint's classification system. Maximum Curvature Points (MCP) are generally used for finger vein image extraction which is also used as authentication. MCP performance will be compared to common method in finger print recognition, Hit and Miss Transform (HMT). Using different domains, spatial in Normalized Cross Correlation (NCC) and frequency in Phase Correlation (PC) affect the system performance. The results show that the application of HMT-NCC more accurate in terms of finger print's recognition, 92\% in accuracy for thumb recognition and 98\% accuracy for index finger recognition, while MCP-PC is only reach $88 \%$ in accuracy for thumb recognition and $92 \%$ accuracy for index finger recognition.
\end{abstract}

Keywords: fingerprint, MCP, HMT, phase correlation, normalized cross correlation 
Prasasti, dkk.

\section{PENDAHULUAN}

Biometrik adalah salah satu teknologi yang digunakan untuk mengidentifikasi individu berdasarkan fitur fisiologis atau perilaku seperti sidik jari, wajah, pembuluh darah, iris, dan geometri tangan (Yamada \& Endoh, 2012). Sidik jari adalah salah satu sistem biometrik yang dimiliki tiap individu yang bersifat unik dan memiliki pola yang berbeda-beda dan permanen, serta lebih mudah dan lebih akurat bila dibandingkan dengan biometrik lainnya. Karena itu, sidik jari sering dijadikan sebagai identitas (Tjandra \& Kistijantoro, 2018). Autentikasi sidik jari adalah salah satu metode identifikasi individu yang paling dapat diandalkan dan banyak digunakan (Shinde \& Bendre, 2015) hal ini dikarenakan autentikasi sidik jari dapat melindungi keamanan sistem dan meningkatkan efisiensi sistem (Xu \& Deng, 2016).

Pada tahun 2011, (Rong, dkk, 2011) telah melakukan penelitian pengenalan sidik jari menggunakan metode Directional Filter Bank (DFT) dan matching berdasarkan normalized euclidean distance, dimana Equal Error Rate (EER) yang didapatkan sebesar 6.15\%. Pada tahun 2014, dilakukan penelitian pengenalan sidik jari dan ekstraksi fitur menggunakan empat metode Transform Domain Techiques (TDT) yaitu gabor filter, fast fourier transform, discrete cosine transform dan discrete wavelet transform menghasilkan akurasi rata-rata terbesar hingga $90.5 \%$ (Tewari \& Kalakoti, 2014). Pada tahun yang sama, telah dilakukan penelitian pengenalan sidik jari menggunakan metode polar histogram dengan melakukan pencocokan citra melalui lokasi relatif pada ekstraksi fitur pusat pori citra sidik jari, dengan Equal Error Rate (EER) 10.46\% (Cui, dkk, 2014). Pada tahun 2015, telah dilakukan proses matching sidik jari menggunakan metode Local Binary Patterns (LBP) dan ekstraksi minutiae yang menghasilkan akurasi sebesar $80 \%$ (Monika \& Kumar, 2014).

Maximum Curvature Points adalah salah satu metode segmentasi citra pembuluh darah. Pada tahun 2015 telah dilakukan penelitian segmentasi citra pada pengenalan vena jari menggunakan metode Maximum Curvature Points dengan tingkat akurasi sebesar $83.92 \%$ dan presisi sebesar 94.28\% (Prasasti, dkk, 2015). Pada tahun 2016 dilakukan penelitian pencocokan citra sidik jari menggunakan metode Phase Correlation. Metode ini mengkorelasikan dua buah citra digital berdasarkan nilai fasa-nya. Citra digital dalam domain spasial diubah ke dalam domain frekuensi menggunakan fast fourier transform untuk mengambil nilai fasa-nya dengan nilai Equal Error Rate (EER) sebesar 1.70\% (Shabrina, dkk, 2016).

Hit and Miss Transform adalah operasi morfologi umum yang dapat digunakan untuk mencari pola tertentu dari piksel latar objek dan latar belakang dalam suatu gambar. Pada tahun 2010, telah dilakukan penelitian ekstraksi fitur pada pengenalan sidik jari berdasarkan metode Hit and Miss Transform (HMT) dengan tingkat sensitivity $98.3 \%$ dan tingkat specificity 93.2\% (Bansal, dkk, 2010). Pada tahun 2016, dilakukan penelitian pencocokan citra sidik jari menggunakan metode Normalized Cross Correlation (NCC). NCC merupakan metode yang digunakan sebagai alat untuk memprediksi korelasi antara nilai $x$ dan $y$ dalam suatu sistem, dengan Equal Error Rate (ERR) sebesar 6.0\% (Derman \& Keskinöz, 2016).

Berdasarkan penelitian yang sudah dilakukan sebelumnya, diketahui bahwa terdapat penemuan metode autentikasi bukan hanya dari sidik jari, melainkan dari pembuluh darah jari. Penelitian ekstraksi ciri gambar pembuluh darah jari menggunakan metode Maximum Curvature Points dianggap paling fenomenal karena cukup sulit mengekstrak gambar pembuluh darah jari yang kurang jelas dan terdapat banyak garis putus sambung akibat posisi pembuluh darah yang tidak sejajar di bawah permukaan kulit, yaitu ada yang lebih dekat ke permukaan kulit dan ada juga yang lebih jauh posisinya dari permukaan kulit. 
Metode MCP tersebut akan diujikan pada gambar sidik jari, apakah memberikan pengaruh perbaikan performansi dari metode yang sudah eksis untuk ekstraksi gambar sidik jari, seperti Hit and Miss Transform. Selain itu, pengubahan domain dari spasial ke frekuensi juga diuji, apakah memberikan perbaikan performansi dari metode yang sudah umum digunakan, yaitu Normalized Cross Correlation. Peneliti membuat sistem pengenalan sidik jari menggunakan metode Hit and Miss Transform untuk ekstraksi fitur dan Normalized Cross Correlation untuk matching dan akan dibandingkan dengan metode Maximum Curvature Points untuk ekstraksi fitur dan Phase Correlation untuk matching. Rumusan masalah yang akan dibahas pada sistem ini antara lain adalah merancang sistem pengenalan sidik jari menggunakan metode HMT dan NCC, merancang sistem pengenalan sidik jari menggunakan metode MCP dan PC, menganalisis dan membandingkan performansi sistem berdasarkan tingkat akurasi dari masing-masing metode, dan menganalisis tingkat response time sistem pengenalan sidik jari. Dengan demikian dapat ditentukan metode yang paling tepat untuk diaplikasikan merujuk kepada hasil pengujian performansi yang dihasilkan.

\section{METODOLOGI PENELITIAN}

\subsection{Algoritma Maximum Curvature Points}

Menurut (Prasasti, dkk, 2015), algoritma Maximum Curvature Points dengan input preprocessing image adalah sebagai berikut:

1. Cross Sectional Profile Pf(z).

Horizontal, Vertical, $45^{\circ}$ kebawah, $45^{\circ}$ ke atas.
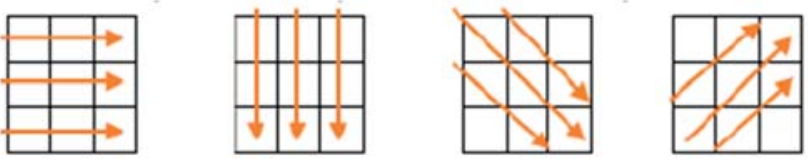

Gambar 1. Cross Sectional Profile

2. Curveture of Profile, menghitung nilai positif yang akan menjadi pusat sidik jari.

$$
k(z)=\frac{d^{2} P_{f}(z) / d z^{2}}{\left\{1+\left(\frac{d P_{f}(z)}{d z}\right)^{2}\right\}^{\frac{3}{2}}}
$$

3. Scoring, merupakan tinggi (intensitas) dikali dengan lebar wilayah kelengkungan positif.

$$
S_{c r}\left(z^{\prime}{ }_{i}\right)=k\left(z^{\prime}{ }_{i}\right) \times W_{r}(i)
$$

4. Mapping, merupakan proses memetakan score ke dalam frame baru yaitu $\mathrm{V}(\mathrm{x}, \mathrm{y})$.

$$
V\left(x^{\prime}{ }_{i}, y^{\prime}{ }_{i}\right)=V\left(x^{\prime}{ }_{i}, y^{\prime}{ }_{i}\right)+S_{c r}\left(z^{\prime}{ }_{i}\right)
$$

5. Neighboorhood Checking, merupakan proses pengecekan piksel ketetanggan. Pengecekan dilakukan dengan mengecek 2 piksel ke kanan dan 2 piksel ke kiri. Proses ini diilustrasikan pada Gambar 2.

$$
C_{d 1}(x, y)=\min \{\max (\mathrm{V}(x+1, y), V(x+2, y))+\max (V(x-1, y), V(x-2, y))\}
$$




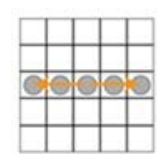

(a)

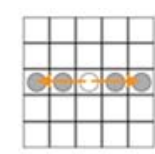

(b)

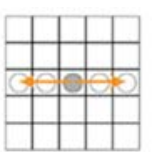

(c)

(a) Menghubungkan Garis (b) Membuat Celah (c) Menghilangkan Noise Gambar 2. Neighboorhood Checking

6. Thresholding, merupakan proses pemberian nilai ambang atau threshold pada citra sidik jari.

$$
G(x, y)=\operatorname{Max}\left(C_{d 1}, C_{d 2}, C_{d 3}, C_{d 4}\right)
$$

7. Labeling, merupakan proses binerisasi dengan ketentuan bernilai 1 jika $(x, y) \geq T$, jika tidak maka bernilai 0 .

\subsection{Algoritma Hit and Miss Transform}

Menurut (Bansal, dkk, 2010), algoritma Hit and Miss Transform dengan input preprocessing image adalah sebagai berikut:

1. Melakukan proses erosi pada citra latar objek dan latar belakang

$$
A * S=\left(A \otimes S_{1}\right) \cap\left(A^{c} \otimes S_{2}\right)
$$

Dimana $A$ adalah citra latar objek dan $A^{c}$ adalah citra latar belakang, sedangkan $S_{1}$ dan $S_{2}$ adalah kernel.

2. Mencari nilai selisih diantara citra latar objek dan latar belakang

$$
A \otimes S=(A \ominus X) \cap\left(A^{c} \ominus(W-X)\right)
$$

Dimana $X$ adalah kernel hit pada latar objek dan $W-X$ adalah kernel miss pada latar belakang.

\subsection{Algoritma Phase Correlation}

Menurut (Shabrina, dkk, 2016), algoritma dari Phase Correlation adalah sebagai berikut:

1. Mengubah dua buah gambar ke domain frekuensi, yaitu menggunakan transformasi fourier diskrit 2D melalui Persamaan (8).

$$
F\left(k_{1}, k_{2}\right)=\sum_{m=0}^{m} \sum_{n=0}^{n} f(m, n) \cdot e^{-j 2 \pi\left(\frac{k_{1} m_{0}}{m}+\frac{k_{2} n_{0}}{n}\right)}
$$

Dimana $F\left(k_{1}, k_{2}\right)$ adalah gambar pada saat $k_{1}$ dan $k_{2}, f(m, n)$ merupakan nilai piksel pada saat ( $\mathrm{m}=$ baris, dan $\mathrm{n}=$ kolom), $\mathrm{e}=$ nilai eksponen.

2. Hitung nilai cross power spectrum dengan Persamaan (9).

$$
R_{j, k}=\frac{G_{a, j k} \cdot G_{b, j k}^{*}}{\left|G_{a, j k} \cdot G_{b, j k}^{*}\right|}
$$

Dimana $R_{j, k}$ adalah nilai cross power spectrum, $G_{a, j k}$ merupakan hasil DFT dari gambar $\mathrm{A}, G_{b, j k}^{*}=$ hasil conjugate dari DFT gambar B. 
3. Lakukan invers pada nilai cross power spectrum, dengan Persamaan (10):

$$
r=F^{-1}\{R\}
$$

Dimana $r=$ hasil invers, $\mathrm{R}=$ nilai cross power spectrum.

4. Tentukan posisi puncak pada nilai $r$ dengan rumus:

$$
(\Delta x, \Delta y)=\operatorname{argmax}\{r\}
$$

Dimana $\Delta x=$ merupakan nilai fasa maksimum pada gambar $\mathrm{X}$, dan $\Delta y$ merupakan nilai fasa maksimum pada gambar $Y$.

$$
\Delta x=\frac{r_{(1,0)}}{r_{(1,0)} \pm r_{(0,0)}}
$$

Dimana $r_{(1,0)}$ adalah nilai maksimum, $r_{(0,0)}$ adalah nilai tetangga terdekat pada sumbu $\mathrm{x}$.

\subsection{Algoritma Normalized Cross Correlation}

Menurut (Insankeovilay, dkk, 2011), algoritma dari Normalized Cross Correlation adalah sebagai berikut :

$$
\operatorname{norm}_{-} \operatorname{corr}(x, y)=\frac{\sum_{n=0}^{n-1} f(x, y) t(x, y)}{\sqrt{\sum_{n=0}^{n-1} f(x, y)^{2} * \sum_{n=0}^{n-1} t(x, y)^{2}}}
$$

Dimana $n$ adalah jumlah piksel di dalam citra $f(x, y)$ dan $t(x, y)$. Nilai Normalized Cross Correlation diperoleh dengan membandingkan korelasi citra di dalam storage dengan input citra sidik jari. Citra yang memiliki nilai korelasi tertinggi akan dianggap sebagai citra sidik jari yang sama.

\subsection{Gambaran Umum Sistem}

Gambar 3 menunjukkan sistem pengenalan sidik jari yang dibuat dengan penjelasan sebagai berikut:

1. Pengguna melakukan capture citra sidik jari menggunakan sensor sidik jari.

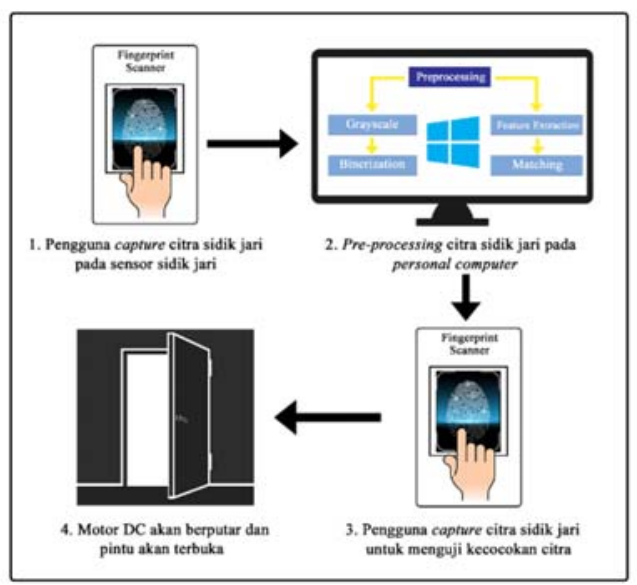

Gambar 3. Gambaran Umum Sistem 
Prasasti, dkk.

2. Citra tersebut diproses oleh personal computer untuk dilakukan proses pre-processing.

3. Pengguna meng-capture kembali citra sidik jari sebagai citra uji untuk melakukan pencocokan dan melihat tingkat kesesuaian sidik jari.

4. Ketika citra sidik jari sesuai maka sistem akan menggerakkan motor DC dan pintu terbuka.

\subsection{Desain Kebutuhan Perangkat Keras}

Sistem yang dibuat membutuhkan beberapa perangkat keras seperti yang ditunjukkan pada Gambar 4.

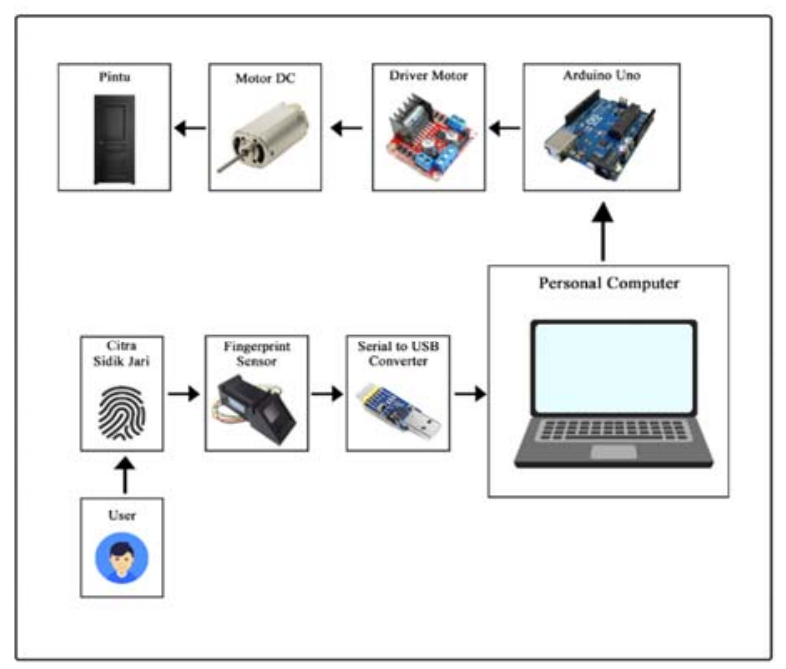

\section{Gambar 4. Kebutuhan Perangkat Keras}

Personal computer digunakan sebagai pusat kontrol sistem dalam mengatur jalur input output data. Pengguna memasukan citra sidik jari melalui sensor sidik jari. Data citra yang telah di-capture oleh sensor sidik jari akan menjadi data masukan untuk personal computer yang kemudian akan diolah dan disimpan ke dalam storage. Pada saat program berjalan, pengguna diminta untuk memasukkan data citra uji. Citra uji tersebut diterima oleh personal computer, maka program akan membandingkan tingkat kecocokan antara citra uji dengan seluruh citra pada storage untuk mencari citra yang paling sesuai. Apabila citra sesuai, personal computer akan memberikan nilai pada arduino uno. Jika nilai tidak sama dengan -1 , maka driver motor akan mengontrol motor DC untuk bergerak.

\subsection{Desain Sistem}

Dalam perancangan dan implementasinya, sistem yang dibuat terdiri dari 4 tahap yaitu akuisisi gambar, atau pengambilan citra sidik jari, preprocessing untuk mendapatkan kualitas citra terbaik, ekstraksi fitur untuk mendapatkan ciri-ciri khusus pada tiap citra sidik jari, dan matching untuk pencocokan citra sidik jari. Keempat tahap tersebut ditunjukan pada diagram blok seperti pada Gambar 5.

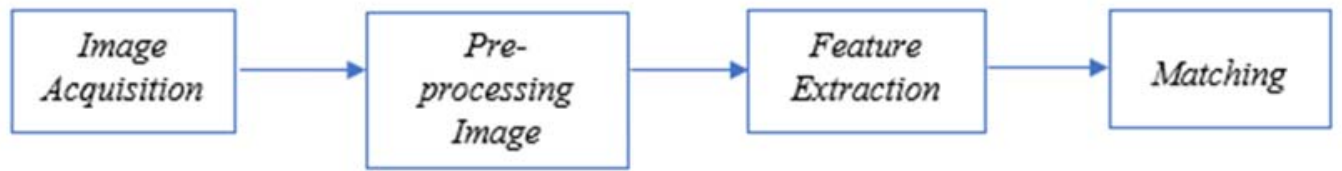

Gambar 5. Diagram Blok Sistem Pengenalan Sidik Jari 
Sistem dibuat menggunakan bahasa pemrograman python 3.6. Tahap awal adalah proses akuisisi citra sidik jari atau pengambilan citra sidik jari menggunakan sensor sidik jari. Setelah citra didapatkan, citra sidik jari tersebut mengalami proses preprocessing untuk menghilangkan noise yang tidak diperlukan. Lalu dilakukan proses ekstraksi fitur untuk mencari ciri khusus atau informasi penting dari citra sidik jari yang kemudian akan di simpan pada storage. Citra tersebut dijadikan sebagai citra template untuk dibandingkan dengan citra uji pada proses matching.

\subsection{Akuisisi Citra}

Tahap ini merupakan proses untuk pengambilan citra sidik jari menggunakan sensor sidik jari. Proses ini menghasilkan gambar sidik jari dengan format .bmp yang ditunjukkan pada Gambar 6.

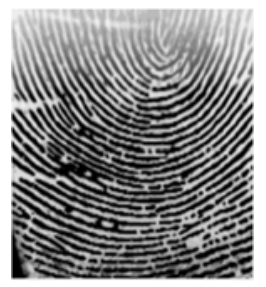

Gambar 6. Contoh Hasil Akuisisi Citra dengan Sensor Sidik Jari

\subsection{Preprocessing}

Tahap ini merupakan proses yang dilakukan setelah mendapatkan citra sidik jari. Citra sidik jari yang sudah didapatkan mengalami proses grayscale. Proses ini bertujuan untuk mengubah agar warna citra sidik jari hanya pada tingkat keabuan saja. Selain itu proses ini juga bertujuan untuk menyederhanakan model citra dan mempermudah proses perhitungan. Kemudian citra hasil grayscale dikonversi ke citra biner, pada proses ini ditentukan nilai ambang atau threshold. Nilai ini digunakan untuk mengubah citra grayscale ke dalam dua nilai yaitu hitam dan putih.

\subsection{Ekstraksi Fitur}

Pada penelitian ini penulis akan melihat hasil perbandingan dari 2 metode ekstraksi ciri yaitu menggunakan Maximum Curvature Points dan Hit and Miss Transform.

\section{Maximum Curvature Points}

Adapun algoritma pada metode Maximum Curvature Points adalah sebagai berikut:

1. Menentukan posisi pusat sidik jari dengan Persamaan (1).

Jika hasilnya bernilai positif, maka pada titik tersebut dibuat cekung. Lakukan perhitungan ini untuk mencari nilai maksimum lokal di setiap area cekung.

2. Menghitung nilai probabilitas posisi pusat sidik jari dengan rumus pada persamaan (2). Nilai probabilitas tiap area cekung dihitung dan ditempatkan nilai probabilitas masing-masing ke dalam frame baru dengan Persamaan (3).

3. Pengecekan piksel ketetanggaan, pengecekan dilakukan pengecekan piksel 2 ke kanan dan 2 ke kiri. Jika nilai piksel di pusat sidik jari dan di kedua sisi memiliki nilai besar, garis ditarik secara horizontal. Ketika pusat sidik jari memiliki nilai piksel lebih kecil dari kedua sisi, garis digambar dengan celah pada pusat sidik jari. Ketika probabilitas pusat sidik jari memiliki nilai yang besar dan piksel di kedua sisi memiliki nilai-nilai kecil, titik noise berada di pusat sidik jari.

4. Pemberian threshold dan labelling, pelabelan dilakukan dengan melakukan proses binerisasi dengan ketentuan nilai 1 jika $(x, y) \geq T$, jika tidak maka 0 . Piksel dengan nilai yang lebih kecil dari threshold akan diberi label sebagai bagian latar belakang (background). Sedangkan piksel yang memiliki nilai lebih besar atau sama dengan nilai threshold akan diberi label sebagai bagian dari wilayah sidik jari. 
Hasil ekstraksi fitur Maximum Curvature Points ditunjukkan pada Gambar 8.

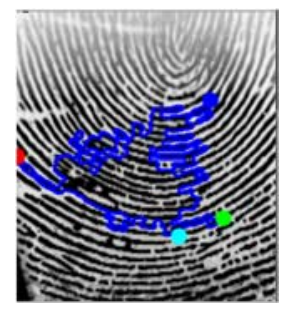

Gambar 7. Hasil ekstraksi fitur Maximum Curvature Points

2. Hit and Miss Transform

Adapun algoritma pada metode Hit and Miss Transform adalah sebagai berikut:

Pada proses hit and miss citra masukkan akan dibagi menjadi dua bagian, yaitu latar objek dan latar belakang. Detail proses algoritma ini ditunjukkan oleh Gambar 8-15.

1. Melakukan proses hit $\left(A \ominus S_{1}\right)$ pada citra latar objek dan miss $\left(A^{c} \ominus S_{2}\right)$ pada citra latar belakang menggunakan nilai kernel

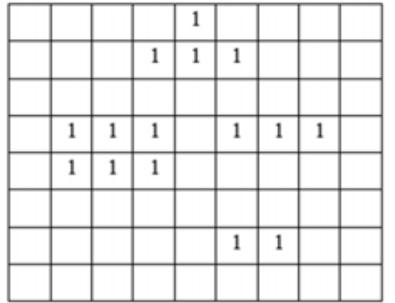

Gambar 8. Nilai Masukkan Latar Objek $(A)$

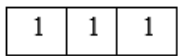

Gambar 10. Nilai Kernel $S_{1}$

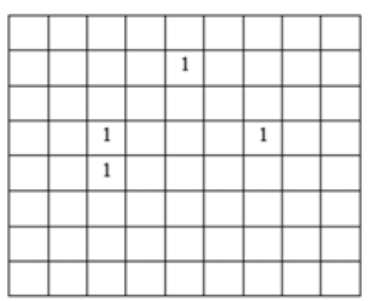

Gambar 12. Nilai $(A)$ Setelah Proses Hit

\begin{tabular}{|l|l|l|l|l|l|l|l|l|}
\hline 1 & 1 & 1 & 1 & & 1 & 1 & 1 & 1 \\
\hline 1 & 1 & 1 & & & & 1 & 1 & 1 \\
\hline 1 & 1 & 1 & 1 & 1 & 1 & 1 & 1 & 1 \\
\hline 1 & & & & 1 & & & & 1 \\
\hline 1 & & & & 1 & 1 & 1 & 1 & 1 \\
\hline 1 & 1 & 1 & 1 & 1 & 1 & 1 & 1 & 1 \\
\hline 1 & 1 & 1 & 1 & 1 & & & 1 & 1 \\
\hline 1 & 1 & 1 & 1 & 1 & 1 & 1 & 1 & 1 \\
\hline
\end{tabular}

Gambar 9. Nílaí Masukkan Latar Belakang $\left(A^{c}\right)$

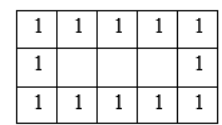

\section{Gambar 11. Nilai Kernel $S_{2}$}

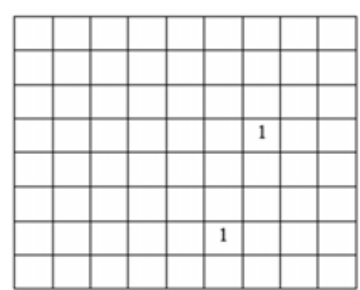

Gambar 13. Nilai $\left(A^{c}\right)$ Setelah Proses Miss

2. Mencari selisih nilai latar objek $(A)$ dan nilai latar belakang $\left(A^{c}\right)$

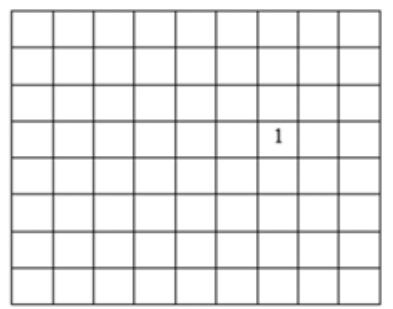

Gambar 14. Nilai Selisih Latar Objek $(A)$ dan Latar Belakang $\left(A^{c}\right)$. 


\section{Gambar 15. Hasil Ekstraksi Fitur Hit and Miss Transform}

\subsection{Matching}

Pada penelitian ini penulis juga akan membandingkan hasil yang diperoleh dengan menggunakan metode Phase Correlation dengan Normalized Cross Correlation.

\section{Phase Correlation}

Phase Correlation merupakan salah satu teknik pencocokan berdasarkan nilai fasa dalam pengolahan citra digital. Citra dalam domain spasial diubah ke dalam domain frekuensi. Pada domain frekuensi, terdapat nilai fasa yang dihitung menggunakan persamaan korelasi untuk mencocokkan dua buah citra. Citra dianggap sangat cocok atau identik jika memiliki nilai korelasi 1 dan sebaliknya dianggap tidak cocok (unmatch) jika nilai korelasi nol. Berikut algroritma dari Phase Correlation:

1. Diasumsikan terdapat 2 buah gambar (Gambar 16 dan 17) dengan masing-masing nilai matriks sebagai berikut:

\begin{tabular}{|l|l|l|}
\hline 0 & 1 & 1 \\
\hline 1 & 1 & 0 \\
\hline 1 & 1 & 0 \\
\hline
\end{tabular}

Gambar 16. Matriks Gambar A

\begin{tabular}{|l|l|l|}
\hline 0 & 1 & 1 \\
\hline 1 & 1 & 0 \\
\hline 1 & 1 & 0 \\
\hline
\end{tabular}

Gambar 17. Matriks Gambar B

Lakukan proses transformasi fourier diskrit 2D pada masing-masing gambar, dengan menggunakan Persamaan (1).

Untuk gambar A :

$$
F\left(k_{1}, k_{2}\right)=\sum_{m=0}^{3} \sum_{n=0}^{3} f(m, n) \cdot e^{-j 2 \pi\left(\frac{k_{1} m_{0}}{3}+\frac{k_{2} n_{0}}{3}\right)}
$$

$$
\begin{aligned}
& \text { Untuk } \mathrm{F}=(0,0)=>\quad \sum_{m=0}^{3} \sum_{n=0}^{3}\left[\left(0 . e^{-j 2 \pi\left(\frac{0.1}{3}+\frac{0.1}{3}\right)}\right)+\left(1 . e^{-j 2 \pi\left(\frac{0.1}{3}+\frac{0.2}{3}\right)}\right)+\right. \\
& \left(1 . e^{-j 2 \pi\left(\frac{0.1}{3}+\frac{0.3}{3}\right)}\right)+\left(1 . e^{-j 2 \pi\left(\frac{0.2}{3}+\frac{0.1}{3}\right)}\right)+\left(1 . e^{-j 2 \pi\left(\frac{0.2}{3}+\frac{0.2}{3}\right)}\right)+\left(0 . e^{-j 2 \pi\left(\frac{0.2}{3}+\frac{0.3}{3}\right)}\right)+ \\
& \left.\left(1 . e^{-j 2 \pi\left(\frac{0.3}{3}+\frac{0.1}{3}\right)}\right)+\left(1 . e^{-j 2 \pi\left(\frac{0.3}{3}+\frac{0.2}{3}\right)}\right)+\left(0 . e^{-j 2 \pi\left(\frac{0.3}{3}+\frac{0.3}{3}\right)}\right)\right] \\
& \mathrm{F}(1,1)=\left[\left(0 . e^{0}\right)+\left(1 . e^{0}\right)+\left(1 . e^{0}\right)+\left(1 . e^{0}\right)+\left(1 . e^{0}\right)+\left(0 . e^{0}\right)+\left(1 . e^{0}\right)+\left(1 . e^{0}\right)+\right. \\
& \left.\left(0 . e^{0}\right)\right] \\
& \mathrm{F}(1,1)=[0+1+1+1+1+0+1+1+0] \\
& \mathrm{F}(1,1)=6
\end{aligned}
$$


Gunakan rumus ini untuk mendapatkan nilai pada masing-masing piksel, mulai dari $F(0,0)$ sampai dengan $F(3,3)$. Sehingga hasil dari transformasi fourier seperti pada Tabel 1 berikut:

\section{Tabel 1. Hasil Proses DFT 2 Dimensi Gambar A}

\begin{tabular}{|c|c|c|}
\hline 6 & 0 & $-2-3.46 \mathrm{i}$ \\
\hline 0 & $-1.27-4.73 \mathrm{i}$ & 0 \\
\hline 0 & 0 & 0 \\
\hline
\end{tabular}

Pada Tabel 1 di atas menunjukan nilai masing-masing tiap piksel. Selanjutnya memisahkan hasil DFT dalam bentuk magnitude dan fasa, hasilnya dapat dilihat pada Tabel 2 dan Tabel 3.

Tabel 2. Hasil dalam Bentuk Magnitude

\begin{tabular}{|l|c|c|}
\hline 6 & 0 & 4 \\
\hline 0 & 4.8990 & 0 \\
\hline 0 & 0 & 0 \\
\hline
\end{tabular}

Tabel 3. Hasil dalam Bentuk Fasa

\begin{tabular}{|c|c|c|}
\hline 0 & 0 & -2.0994 \\
\hline 0 & -1.8326 & 0 \\
\hline 0 & 0 & 0 \\
\hline
\end{tabular}

Dalam hal ini, Phase Correlation hanya membutuhkan nilai fasa dari suatu gambar. Lakukan hal yang sama untuk mencari nilai fasa dari gambar kedua yang ingin di cocokkan.

2. Setelah mendapatkan hasil dari masing-masing gambar, selanjutnya adalah menghitung nilai cross power spectrum dengan catatan melakukan conjugate pada gambar kedua. Conjugate artinya tidak mengubah tanda pada nilai magnitude tetapi mengubah tanda pada nilai fasa. Dengan menggunakan persamaan:

$$
\begin{gathered}
R_{j, k}=\frac{G_{a, j k} \cdot G_{b, j k}^{*}}{\left|G_{a, j k} \cdot G_{b, j k}^{*}\right|} \\
R_{j, k}=\frac{\left|G_{b, j k}^{*}\right|^{2} \cdot e^{-j 2 \pi\left(\frac{k_{1} m_{0}}{3}+\frac{k_{2} n_{0}}{3}\right)}}{\left|G_{b, j k}^{*}\right|^{2}} \\
R_{j, k}=e^{-j 2 \pi\left(\frac{k_{1} m_{0}}{3}+\frac{k_{2} n_{0}}{3}\right)}
\end{gathered}
$$

Diasumsikan Gambar B memiliki hasil dari DFT sebagai berikut:

$$
\mathrm{B}=\left(\begin{array}{ccc}
6 & 0 & -2-3.46 i \\
0 & -1.27-4.73 i & 0 \\
0 & 0 & 0
\end{array}\right)
$$

Maka, nilai cross power spectrum dari matriks tersebut adalah nilai fasanya saja, yaitu:

$$
R_{j, k}=\left(\begin{array}{ccc}
0 & 0 & -2.0994 \\
0 & -1.8326 & 0 \\
0 & 0 & 0
\end{array}\right)
$$


Perbandingan Ekstraksi Ciri dan Proses Matching pada Autentikasi Sidik Jari Manusia

3. Kemudian, lakukan invers dari hasil yang diperoleh dari cross power spectrum. Selanjutnya mencari lokasi maksimal pada nilai $r$ dengan persamaan:

$$
(\Delta x, \Delta y)=\operatorname{argmax}\{r\}
$$

Untuk $\Delta x=$

$$
\begin{aligned}
& x(1,3)=\frac{r_{(1,0)}}{r_{(1,0)} \pm r_{(0,0)}}=\frac{-2.0994}{-2.0994 \pm 0}=1 \\
& x(2,2)=\frac{r_{(1,0)}}{r_{(1,0)} \pm r_{(0,0)}}=\frac{-1.8326}{-1.8326 \pm 0}=1
\end{aligned}
$$

Untuk $\Delta y=$

$$
\begin{aligned}
& y(3,1)=\frac{r_{(1,0)}}{r_{(1,0)} \pm r_{(0,0)}}=\frac{-2.0994}{-2.0994 \pm 0}=1 \\
& y(2,2)=\frac{r_{(1,0)}}{r_{(1,0)} \pm r_{(0,0)}}=\frac{-2.0994}{-2.0994 \pm 0}=1
\end{aligned}
$$

Pada nilai fasa maksimum, nilai yang dihasilkan adalah 1 , artinya gambar $\mathrm{A}$ dengan gambar B merupakan gambar yang sama.

\section{Normalized Cross Correlation}

Normalized Cross Correlation merupakan metode yang digunakan sebagai alat untuk memprediksi korelasi antara nilai $x$ dan $y$ dalam suatu sistem. Berikut algoritma dari nilai NCC:

$x=\left[\begin{array}{lll}3 & 2 & 1 \\ 4 & 5 & 6 \\ 7 & 3 & 2\end{array}\right] \quad y=\left[\begin{array}{ccc}2 & 3 & 1 \\ 4 & 7 & 10 \\ 8 & 3 & 1\end{array}\right] \quad z=\left[\begin{array}{ccc}1 & 6 & 4 \\ 10 & 3 & 2 \\ 1 & 3 & 1\end{array}\right]$

1. Proses cross correlation pada matriks citra $x, y$

$$
\begin{aligned}
\operatorname{corr}_{x, y} & =x[0] y[0]+x[1] y[1]+x[2] y[2]+x[3] y[3] \ldots+x[n] y[n] \\
& =6+6+1+16+35+60+56+9+2=191
\end{aligned}
$$

2. Proses cross correlation pada matriks citra $y, z$

$$
\begin{aligned}
\operatorname{corr}_{y, z} & =y[0] z[0]+y[1] z[1]+y[2] z[2]+y[3] z[3] \ldots+y[n] z[n] \\
& =2+18+4+40+21+20+8+9+1=123
\end{aligned}
$$

3. Proses normalized citra $x, y$

$$
\begin{aligned}
\text { norm } & =\sqrt[2]{(9+4+1+16+25+36+49+9+4)(4+9+1+16+49+100+64+9+1)} \\
& =196.74
\end{aligned}
$$

4. Proses Normalized Cross Correlation citra $x, y$

$$
\text { norm }_{\text {corr }_{x, y}}=\frac{191}{196.74}=0.97
$$

5. Proses normalized citra $y, z$

$$
\begin{aligned}
\text { norm } & =\sqrt[2]{(4+9+1+16+49+100+64+9+1)(1+36+16+100+9+4+1+9+1)} \\
& =211.61
\end{aligned}
$$


6. Proses Normalized Cross Correlation citra $y, z$

$$
\text { norm }_{\text {corr }_{y, z}}=\frac{123}{211.61}=0.58
$$

Diketahui bahwa norm $_{\text {corr }_{x, y}}$ memiliki nilai korelasi yang lebih besar dengan nilai 0.97 dibandingkan dengan nilai norm corr $_{y, z}$ dengan nilai 0.58 . Semakin besar nilai, maka semakin besar korelasi di antara dua citra.

\section{HASIL DAN PEMBAHASAN}

Data masukan yang digunakan pada penelitian ini adalah citra sidik jari dengan format (.bmp) yang dipindai menggunakan sensor sidik jari. Jari jempol dan jari telunjuk pada tangan manusia menjadi target objek pada penelitian. Penelitian dilakukan sebanyak 30 kali untuk setiap subyek sidik jari.

\subsection{Perbandingan Akurasi Awal}

Pada percobaan pertama, akan dilihat perbandingan akurasi terhadap citra sidik jari tanpa penambahan proses pre-processing pada kedua penelitian. Hasil perbandingan akurasi yang didapat adalah seperti yang ditunjukkan pada Gambar 18.

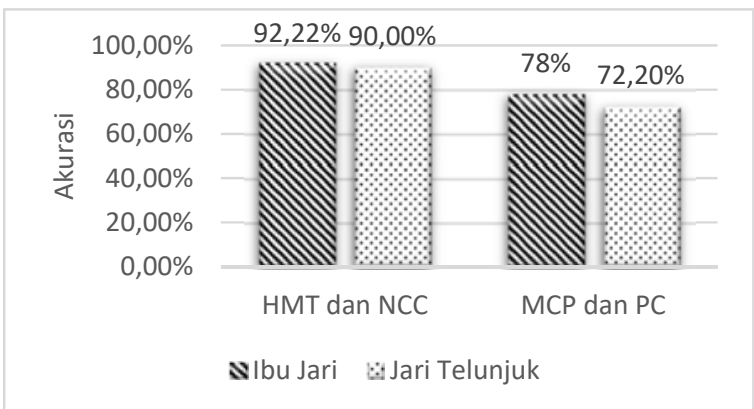

\section{Gambar 18. Perbandingan Akurasi HMT dan NCC dengan MCP dan PC tanpa Pre- processing}

Hasil akurasi tanpa penambahan proses pre-processing pada penelitian menggunakan metode HMT dan NCC memiliki presentase yang lebih baik dibandingkan dengan penelitian menggunakan metode MCP dan PC. Scoring pada MCP digunakan untuk memperhitungkan daerah kurva maksimum untuk mengetahui pola garis di bawah kurva sehingga ketika ada garis yang terputus dapat tersambung kembali. Sementara itu, proses scoring MCP pada gambar sidik jari menyebabkan error pada proses bridging dikarenakan gambar hasil akusisi yang relatif sudah baik. Dapat dilihat pada grafik bahwa metode MCP-PC memiliki performa pengenalan sidik jari lebih rendah $14 \%-18 \%$ dibanding metode HMT-NCC. Kemudian pada proses pengenalan antara sidik ibu jari dan telunjuk, ibu jari dapat lebih dikenali sekitar $2 \%$ $6 \%$ dibandingkan jari telunjuk dikarenakan area sidik jari lebih luas sehingga menghasilkan fitur yang lebih banyak pula jika dibandingkan dengan jari telunjuk sehingga proses pencocokannya juga lebih akurat.

\subsection{Perbandingan dengan Penambahan Pre-processing}

Proses enhancement pada citra digital sangat penting untuk meningkatkan kualitas citra sehingga meningkatkan nilai akurasi pengenalan objek (Aziz, dkk, 2017). Salah satu cara peningkatan kualitas citra adalah dengan menghilangkan noise yang tersebar pada citra (Putra, dkk, 2017). Pada percobaan kedua, dilakukan penambahan proses pre-processing 
dengan tiga parameter, yaitu penambahan parameter gaussian blur, median blur, dan bilateral blur.

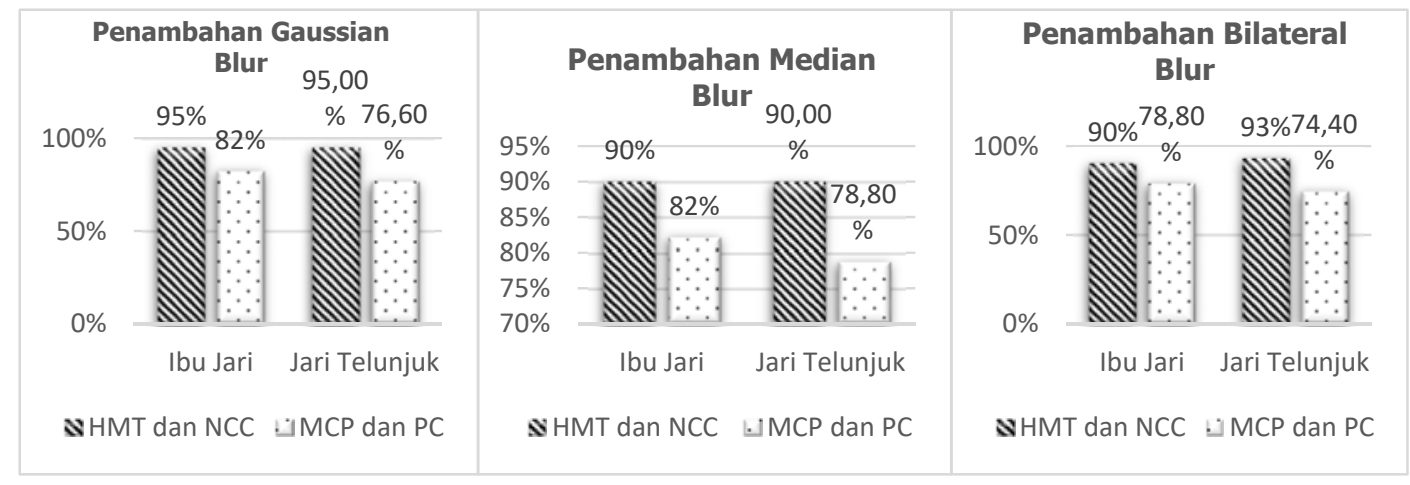

Gambar 19. Hasil Perbandingan Akurasi dengan Penambahan Pre-processing

Dapat dilihat pada Gambar 19, bahwa penambahan parameter pre-processing menyebabkan kenaikan akurasi yang cukup signifikan terutama pada penambahan Gaussian blur yaitu ratarata lebih dari 5\% untuk semua metode. Penambahan Gaussian blur menyebabkan efek gambar yang lebih smooth sehingga noise tipe Gaussian yang tersebar di gambar sidik jari dapat dihilangkan. Penambahan median blur dan bilateral blur tidak memberikan kenaikan akurasi yang cukup signifikan pada metode HMT-NCC dikarenakan hasil filter median dan bilateral juga tidak memberikan perubahan yang signifikan pada gambar hasil akuisisi sidik jari di domain spasial. Namun pada metode MCP-PC, penambahan filter median dapat meningkatkan akurasi sekitar 4\%-7\% karena perhitungan proses matching-nya dilakukan pada domain frekuensi.

\subsection{Perbandingan Respon Time Sistem}

Pada percobaan ketiga dilakukan perhitungan kecepatan respon time pada sistem untuk mengetahui seberapa cepat sistem dapat memindai sidik jari dan mengenali sidik jari. Pemindaian sidik jari memiliki waktu yang cukup lama hingga mencapai 5 detik/subjek. Sedangkan waktu komputasi pada pengenalan sidik jari memiliki respon time yang relatif cepat, yaitu hanya 0,029 detik hingga 0,376 detik. Scanner yang digunakan untuk proses pemindai sidik jari telah memiliki proses enhancement sehingga membutuhkan waktu pemindai yang cukup lama. Pada penelitian ini, menggunakan metode MCP-PC memiliki waktu pengenalan yang lebih lama, yaitu sekitar 0,347 detik dibandingkan dengan menggunakan metode HMT-NCC, hal ini dikarenakan adanya proses pengubahan domain pada MCP-PC dari domain spasial ke domain frekuensi, selain itu proses perhitungannya juga lebih kompleks dibandingkan dengan metode HMT yang hanya menggunakan proses morfologi.

\subsection{Perbandingan pada Kondisi Ideal Sistem}

Pada percobaan keempat dilakukan pengujian sistem dengan kondisi ideal dan telah dilakukan beberapa proses untuk meningkatkan kualitas citra sidik jari. Berikut hasil perbandingan pada Gambar 20. Kondisi ideal didapatkan dengan menambahkan proses enhancement, pengaturan brightness, serta penambahan filter gaussian pada HMT dan filter median pada MCP. Dapat dilihat bahwa penelitian dalam kondisi ideal menggunakan metode HMT-NCC memiliki presentase lebih baik sekitar 4\%-6\% pada kedua subjek jari jempol dan jari telunjuk dibandingkan penelitian menggunakan metode MCP-PC. Hal ini disebabkan metode MCP lebih tepat jika digunakan pada ektraksi fitur pembuluh darah jari daripada sidik 
jari karena memiliki perhitungan scoring untuk garis putus-putus pada bagian kurva maksimum. Sementara pada penelitian ini, gambar hasil akuisisi sidik jari sudah relatif jelas dan baik sehingga proses scoring menyebabkan error pada proses bridging sidik jari yang terputus. Akurasi juga dipengaruhi proses enrollment, yaitu posisi jari saat melakukan proses pemindai. Semakin ditekan kuat jarinya, semakin banyak pola sidik jari yang terakuisisi namun semakin banyak pula kesalahannya karena garis-garis sejajar yang seharusnya terpisah pada sidik jari menjadi tersambung.

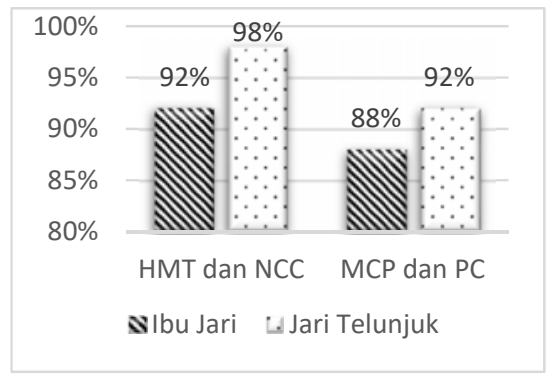

\section{Gambar 20. Hasil Perbandingan pada Kondisi Ideal Sistem}

\section{KESIMPULAN}

Berdasarkan hasil percobaan dan pengujian pada sistem dapat diperoleh kesimpulan bahwa metode MCP menghasilkan akurasi sebesar $88 \%$ untuk mengenali ibu jari dan $92 \%$ untuk mengenali jari telunjuk. Metode HMT menghasilkan akurasi sebesar $92 \%$ untuk mengenali ibu jari dan $98 \%$ untuk mengenali jari telunjuk. Rata-rata respon time sistem dalam melakukan pemindaian pada kedua metode adalah 5 detik, tetapi respon time pengenalan sidik jari lebih cepat menggunakan metode Normalized Cross Correlation yaitu 0.029 ms sedangkan menggunakan metode Phase Correlation adalah 0.376 ms. Berdasarkan hasil pengujian, metode HMT dan Normalized Cross Correlation memiliki tingkat akurasi yang lebih baik dan lebih cepat dalam respon time pengenalan sidik jari dibandingkan dengan metode MCP dan Phase Correlation. Idealnya metode MCP digunakan untuk ekstraksi gambar pembuluh darah di bawah permukaan kulit yg kurang jelas dan terputus-putus. Gambar sidik jari hasil pemindaian yang digunakan sudah cukup jelas sehingga proses pada MCP dianggap kurang tepat karena lebih boros dalam hal komputasi, diiringi proses matching yang menggunakan nilai fasa sehingga butuh proses transformasi kembali citra dari domain spasial ke domain frekuensi. Hal ini menyebabkan akurasinya lebih rendah serta waktu komputasi lebih tinggi. Namun dalam hal ini dapat dibuktikan bahwa ekstraksi fitur MCP tetap mampu melakukan ekstraksi fitur pada citra sidik jari meski tidak menghasilkan performansi yang sebanding dengan metode HMT.

\section{DAFTAR RUJUKAN}

Aziz, M. N., Purboyo, T. W., and Prasasti, A. L. (2017). A Survey on the Implementation of Image Enhancement. Int. J. Appl. Eng. Res., 12(21), 11451-11459.

Bansal, R., Sehgal, P., \& Bedi, P. (2010). Effective Morphological Extraction of True Fingerprint Minutiae based on the Hit or Miss Transform. International Journal of Biometrics and Bioinformatics (IJBB), 4(2), 71-85. 
Cui, J., Ra, M. S., \& Kim, W. Y. (2014). Fingerprint pore matching method using polar histogram. Proceedings of the International Symposium on Consumer Electronics (ISCE), (pp. 1-2). https://doi.org/10.1109/ISCE.2014.6884381

Derman, E., \& Keskinöz, M. (2016). Normalized cross-correlation based global distortion correction in fingerprint image matching. International Conference on Systems, Signals, and Image Processing, (pp. 1-4). https://doi.org/10.1109/IWSSIP.2016.7502727

Insankeovilay, S., Prasarn, P., Choomchuay, S. (2011). Fingerprint Matching with Cross Correlation and Minutiae Scores. IEEE Biomedical Engineering International Conference. https://doi.org/10.1109/BMEiCon.2012.6172045

Monika, \& Kumar, M. (2014). A novel fingerprint minutiae matching using LBP. Proceedings 3rd International Conference on Reliability, Infocom Technologies and Optimization: $\begin{array}{lllll}\text { Trends and } & \text { Future }\end{array}$ https://doi.org/10.1109/ICRITO.2014.7014742

Prasasti, L. A., Mengko, W. K. R., Adiprawita, W. (2015). Vein Tracking Using 880nm Near Infrared and Sensor with Maximum Curvature Points Segmentation. International Federation for Medical and Biological Enginnering (IFMBE), (pp. 206-209).

Putra, R.D., Purboyo, T.W., and Prasasti, L. A. (2017). A Review of Image Enhancement Methods. Int. J. Appl. Eng. Res., 12(23), 13596-13603.

Rong, L. C., Qing, H. M., \& Li, J. (2011). Fingerprint composition-feature extraction using directional filter banks. Proceedings - 2011 7th International Conference on Computational Intelligence and Security, CIS 2011, (pp. 550-554). https://doi.org/10.1109/CIS.2011.127

Shabrina, N., Isshiki, T., \& Kunieda, H. (2016). Fingerprint Authentication on Touch Sensor using Phase-Only Correlation Method. International Conference of Information and Communication Technology for Embedded Systems (IC-ICTES), (pp. 1-5). https://doi:10.1109/ictemsys.2016.7467127

Shinde, A. S., Bendre, V. (2015). An Embedded Fingerprint Authentication System. International Conference on Computing Communication Control and Automation, (pp. 205-208). https://doi.org/10.1109/ICCUBEA.2015.45

Tewari, K., \& Kalakoti, R. L. (2014). Fingerprint recognition and feature extraction using transform domain techniques. IEEE International Conference on Advances in Communication and Computing Technologies, (pp. 1-5). https://doi.org/10.1109/EIC.2015.7230719

Tjandra, M., \& Kistijantoro, I., A. (2018). Fingerprint Indexing based on Ridge Orientation and Frequency on GPU. International Conference on Advanced Computer Science and 
Information Systems (ICACSIS), (pp. 17-21).

$\mathrm{Xu}$, Q., \& Deng, J. I. E. (2016). Identity authentication system based on fingerprint identification and pulse certification. International Conference on Intelligent Networking and Collaborative Systems, (pp. 280-284). https://doi.org/10.1109/INCoS.2016.84

Yamada, S., \& Endoh, T. (2012). Evaluation of Independence between Palm Vein and Fingerprint for Multimodal Biometrics. Proceedings of the International Conference of Biometrics Special Interest Group, (pp. 341-349). 